\title{
PERAN CITRA TOKO DALAM MEMEDIASI HUBUNGAN KUALITAS PELAYANAN DENGAN NIAT BELI ULANG
}

\author{
I Kadek Dicki Darma Putra ${ }^{1}$ \\ I Gusti Agung Ketut Sri Ardani ${ }^{2}$ \\ ${ }^{1,2}$ Fakultas Ekonomi dan Bisnis Universitas Udayana, Bali, Indonesia \\ email: darma.dicki@yahoo.co.id
}

\begin{abstract}
ABSTRAK
Bisnis ritel di Indonesia berkembang sangat pesat. Hadirnya gerai ritel berskala kecil akan menjadi ancaman untuk perusahaan ritel berskala besar seperti Hypermart. Tujuan dari penelitian ini adalah untuk menjelaskan pengaruh kualitas pelayanan terhadap citra toko, kualitas pelayanan terhadap niat beli ulang, citra toko terhadap niat beli ulang, serta peran citra toko dalam memediasi pengaruh kualitas pelayanan terhadap niat beli ulang. Penelitian ini dilakukan pada konsumen Hypermart Mall Bali Galeria yang berdomisili di Kota Denpasar. Ukuran sampel yang diambil sebanyak 120 orang dengan metode purposive sampling. Hasil penelitian menemukan bahwa kualitas pelayanan berpengaruh positif dan signifikan terhadap citra toko. Penelitian ini juga menemukan bahwa masing-masing variabel kualitas pelayanan dan citra toko secara signifikan berpengaruh positif terhadap niat beli ulang, selain itu citra toko juga secara signifikan memediasi hubungan kualitas pelayanan terhadap niat beli ulang. Hal ini menunjukkan bahwa semakin baik citra toko dan kualitas pelayanan yang diberikan maka akan meningkatkan niat beli ulang konsumen di Hypermart Mall Bali Galeria.
\end{abstract}

Kata kunci: kualitas pelayanan, citra toko, dan niat beli ulang.

\begin{abstract}
Retail business in Indonesia is growing very rapidly. The presence of small-scale retail outlets will be a threat to large-scale retail companies such as Hypermart. The purpose of this research is to explain the influence of service quality to store image, service quality to re-buy intention, store image to re-buy intention, and store image role in mediating influence of service quality to re-buy intention. This research was conducted on the consumers of Hypermart Mall Bali Galeria domiciled in Denpasar City. The sample size taken as many as 120 people with purposive sampling method. The results of the study found that service quality had a positive and significant effect on store image. The study also found that each variable of service quality and store image significantly positively affects the repurchase intention, in addition to the image of the shop also significantly mediate the relationship of service quality to the intention of buy back. This shows that the better the image of the store and the quality of service provided it will increase the intention of buy back consumers at Hypermart Mall Bali Galeria.
\end{abstract}

Keywords: quality of service, store image, and re-purchase intention. 


\section{PENDAHULUAN}

Perkembangan bisnis ritel di Indonesia, khususnya di Bali, berkembang sangat pesat. Perkembangan bisnis ini ditandai dengan masuknya peritel asing berskala besar dan juga menjamurnya perusahaan ritel berskala kecil yang sering kita jumpai di tengah-tengah masyarakat. Bisnis ritel meliputi seluruh kegiatan penjualan barang dan jasa untuk memenuhi kebutuhan sendiri, keluarga, dan lain sebagainya (Yulianti dkk., 2014).

Kotler et al. (2006: 524) menyatakan bahwa terdapat beberapa tipe bisnis ritel meliputi specialty store (toko khusus), department store (toko serba ada), supermarket (pasar swalayan), convenience store (toko yang menjual kebutuhan sehari-hari), discount store (toko diskon), off-price retailer (pengecer murah) yang terdiri dari factory outlet (outlet pabrik), independent off-price retailers (pengecer independen dengan harga murah), dan warehouse clubs (klub gudang/klub pedagang besar), superstore (toko swalayan super) yang terdiri dari combination stores (toko kombinasi) dan hypermarkets, catalog showroom (ruang pamer katalog).

Menurut Firdiana dan Rahardjo (2016) menjamurnya bisnis ritel tidak lepas dari meningkatnya pendapatan masyarakat, meningkatnya jumlah penduduk, bertambahnya kelas menengah (middle class), urbanisasi, tingkat optimisme konsumen yang kuat, dan pertumbuhan properti komersial yang menjadi driver permintaan industri ritel.

Kebutuhan konsumsi masyarakat yang semakin meningkat akan menimbulkan dibukanya gerai-gerai ritel dengan skala yang kecil. Pada saat ini 
perkembangannya diperkirakan tiap tahun naik sekitar 14 persen - 15 persen, dalam rentang waktu tahun 2004 sampai dengan 2010. Format minimarket memiliki rata-rata pertumbuhan paling tinggi yaitu sebesar 38,5 persen per tahun, disusul kemudian oleh hypermarket sebesar 21,5 persen dan supermarket yang hanya 6 persen per tahun (Purnama, 2016).

Masyarakat lebih memilih gerai dengan skala kecil karena lokasi yang mudah dijangkau, kemudahan dalam tempat parkir, harga yang menarik dan relatif terjangkau (Purnama, 2016). Hal tersebut tentu menjadi ancaman bagi perusahaan ritel berskala besar. Maka dari itu peritel berskala besar harus memiliki cara untuk mendapatkan konsumennya. Salah satu bentuk ritel berskala besar adalah hypermarket.

Hypermarket adalah toko yang sangat besar dengan luas antara 80.000 dan 200.000 kaki persegi, merupakan kombinasi pasar swalayan, toko diskon, dan pengecer gudang (Kotler, 2003: 536). Produk yang dijual meliputi produk makanan dan kebutuhan sehari-hari, mebel, peralatan, pakaian, dan barang lainnya. Hypermarket mengutamakan display barang dalam jumlah dan variasi dengan penanganan minimum oleh personel toko.

Toko ritel di kota Denpasar dibagi menjadi beberapa kelas dari yang rendah sampai yang tinggi meliputi 295 minimarket, 41 supermarket dan 3 hypermarket yang aktif dalam menyediakan semua kebutuhan konsumen, seperti yang dicerminkan dalam tabel dibawah ini. 
Tabel 1.

Jumlah Ritel Modern di Kota Denpasar Tahun 2014

\begin{tabular}{lllll}
\hline Kecamatan & $\begin{array}{l}\text { Luas } \\
(\mathbf{K m 2})\end{array}$ & $\begin{array}{l}\text { Wilayah } \\
\text { Jumlah Ritel Modern (Unit) }\end{array}$ & $\begin{array}{l}\text { Minimarket } \\
\text { Hypermarket }\end{array}$ & Supermarket \\
\hline Denpasar Utara & 3112 & 52 & 0 & 9 \\
$\begin{array}{l}\text { Denpasar } \\
\text { Timur }\end{array}$ & 2524 & 41 & 0 & 3 \\
Denpasar Barat & 2413 & 72 & 0 & 16 \\
$\begin{array}{l}\text { Denpasar } \\
\text { Selatan }\end{array}$ & 4999 & 130 & 3 & 13 \\
Jumlah & 13048 & 295 & 3 & 41 \\
\hline
\end{tabular}

Sumber: data sekunder diolah, 2014

Berdasarkan Tabel 1 jumlah hypermarket yang terdapat di Kota Denpasar sebanyak 3 unit yaitu Hypermart Mall Bali Galeria, Carrefour, dan Lotte Mart. Jika dibandingkan dengan ritel modern lain yang ada di Kota Denpasar, hypermarket memiliki jumlah yang lebih sedikit daripada supermarket atau minimarket, namun hypermarket menawarkan sejumlah besar barang-barang keras maupun barang-barang lunak, menyediakan banyak pelayanan ke konsumen, memiliki volume penjualan yang besar, dan mempekerjakan banyak orang untuk beberapa jenis pekerjaan.

Konsumen cenderung berbelanja di toko-toko dengan citra yang lebih baik. Ketika konsumen memiliki evaluasi positif terhadap toko, maka akan memberikan pengaruh positif pada citra yang dibawa oleh toko. Penelitian Beristain and Zorrilla (2011), menyatakan bahwa citra toko yang baik akan menyebabkan citra merek dan kualitas yang diberikan toko juga akan lebih baik. Nama baik perusahaan yang positif juga mempengaruhi persepsi konsumen terhadap kualitas 
barang dagangannya (Bao et al., 2011). Wu et al. (2011) menyatakan citra toko juga dinilai dari sikap konsumen atau kesan keseluruhan yang berasal dari karakteristik intrinsik dan ekstrinsik toko.

Citra toko yang baik tentu dihasilkan dari kualitas pelayanan yang diberikan oleh perusahan secara optimal. Kualitas pelayanan disini merupakan segala bentuk pelayanan yang diberikan oleh pihak retail kepada konsumen (Sulistiono, 2010). Pelayanan yang dapat memuaskan konsumen akan berdampak terjadinya pembelian berulang-ulang yang berarti akan terjadi peningkatan penjualan. Pelayanan yang baik dapat menciptakan kepuasan dan loyalitas konsumen serta membantu menjaga jarak dengan pesaing (Iswayanti, 2010).

Menurut Agyapong (2011) kualitas pelayanan telah ditemukan di dalam literatur untuk menjadi alat yang kompetitif bagi banyak perusahaan. Bahkan pada kondisi global pada saat ini sangat menuntut perusahaan untuk berkompetitif dalam industri. Wibowo, dkk. (2013) juga menyatakan bahwa kualitas mampu mendorong perusahaan untuk melakukan perbaikan dalam bersaing dengan kompetitor. Hal ini menjadi strategi bagi perusahaan yang memiliki ciri khas atau karakter yang kuat pada produk dan pelayanannya sehingga memuaskan kebutuhan konsumennya.

Menurut Bhuwana dan Sudiksa (2013) kualitas pelayanan dipersepsikan baik dan memuaskan apabila jasa yang diterima atau dirasakan sesuai dengan yang diharapkan. Perusahaan jasa akan memberikan kualitas pelayanan yang baik dengan tujuan untuk menciptakan kepuasan konsumen. Kualitas pelayanan yang 
diberikannya akan menimbulkan persepsi atas kualitas yang diberikannya. Penelitian Widjajanti dan Ernawati (2012) menyatakan bahwa guna mengetahui apakah perusahaan sudah memberikan kualitas jasa yang sesuai dengan harapan konsumen maka perlu dievaluasi dari konsumennya. Perusahaan yang ingin berkembang dan unggul harus dapat memberikan jasa yang berkualitas seperti pelayanan yang lebih baik dibanding pesaingnya

Meningkatkan citra toko dan kualitas pelayanan memiliki tujuan untuk meningkatkan niat beli ulang konsumen, seperti penelitian Yulianti, dkk. (2014) yang menyatakan bahwa kesuksesan sebuah ritel dapat ditandai dengan adanya perilaku pembelian ulang dari para konsumennya dan kemampuan ritel untuk bertahan dalam menghadapi pesaing-pesaingnya, sehingga menimbulkan niat beli ulang dari konsumen menjadi fokus utama ketika citra dan pelayanan telah dirasakan konsumen. Tariq et al. (2013) menyatakan sangat penting menentukan barang yang tepat tentang apa yang konsumen butuhkan karena akan berpengaruh positif dengan niat beli ulang pelanggan.

Triastuti (2012) menyatakan bahwa minat beli ulang merupakan bagian dari perilaku pembelian, yang selanjutnya akan membentuk loyalitas dalam diri konsumen. Selain itu, pelanggan yang memiliki komitmen pada umumnya lebih mudah menerima perluasan produk baru yang ditawarkan oleh perusahaan tersebut. Kesesuaian performa produk dan jasa yang ditawarkan dengan yang diharapkan konsumen akan memberikan kepuasan dan akan menghasilkan minat beli ulang di waktu yang akan datang. Konsumen yang merasa puas akan memberikan rekomendasi positif bagi konsumen lainnya terhadap merek tersebut. 
Survei awal yang dilakukan penulis terhadap 20 orang masyarakat yang dilakukan di kota Denpasar, menemukan bahwa 12 orang lebih memilih untuk berbelanja di minimarket (Indomaret, Alfamart, Minimart, dll) dengan alasan lokasi yang mudah dijangkau karena tersebar di seluruh wilayah Denpasar, dan lebih mempersingkat waktu dalam proses belanja karena lingkup toko yang kecil. Sedangkan 3 orang lebih memilih untuk datang ke supermarket ( Tiara, Hardys, dll) dengan alasan harga yang murah serta dilengkapi dengan wahana hiburan yang menjadi ciri khas supermarket tersebut, dan 5 orang memilih untuk datang ke Hypermarket (Hypermart, Carefour, Lotte Mart) dengan alasan kelengkapan barang dagangan dan suasana toko yang rapi.

Dari ketiga hypermarket yang ada di kota Denpasar, penulis tertarik untuk meneliti Hypermart Mall Bali Galeria sebagai objek penelitian karena pertimbangan intensitas pengunjung Hypermart Mall Bali Galeria tinggi karena berada di dalam mall. Hypermart dirasa memiliki citra dan kualitas pelayanan yang baik sehingga sesuai dengan variabel-variabel yang akan diteliti.

Hypermart adalah jaringan hypermarket yang memiliki banyak cabang di Indonesia. Hypermart Mall Bali Galeria memiliki swalayan yang menjual kebutuhan sandang, barang kebutuhan sehari-hari, peralatan elektronik, dan lainlain. Perjalanan Hypermart merintis langkahnya di Indonesia tidak bisa dikatakan singkat. Mulai beroperasi pada tahun 2004, saat ini Hypermart menunjukkan bahwa ia mampu bersaing dengan peritel lainnya. Kini Hypermart sudah memiliki kurang lebih 100 gerai di seluruh Indonesia (www.hypermart.co.id). 
Tidak mudah bagi Hypermart Mall Bali Galeria agar memenangkan persaingan yang semakin global. Hypermart Mall Bali Galeria harus melakukan strategi agar tetap menjadi pemimpin di pasar. Dari fenomena, masalah dan survei yang sudah dijelaskan, Hypermart Mall Bali Galeria harus tahu apakah kualitas pelayanan mampu mempengaruhi niat beli ulang yang akan dilakukan konsumen. Selain itu, Hypermart Mall Bali Galeria juga harus tahu apakah peran citra toko mampu mendukung kualitas pelayanan agar menimbulkan niat beli ulang di Hypermart Mall Bali Galeria.

Di balik beberapa penelitian yang telah dijabarkan terdapat hasil penelitian yang berbeda dengan hasil penelitian sebelumnya seperti menurut penelitian Agustin (2011) yang menyatakan bahwa kualitas pelayanan tidak berpengaruh signifikan secara langsung terhadap kepuasan pelanggan yang artinya tidak mempengaruhi niat beli ulang konsumen. Berbeda dengan penelitian yang dilakukan oleh Wibowo, dkk. (2013) yang menyatakan bahwa kualitas pelayanan memiliki pengaruh yang positif dan signifikan terhadap niat pembelian ulang. Terjadinya perbedaan penelitian tersebut menimbulkan penggunaan citra toko sebagai mediasi yang didukung oleh penelitian Wu et al. (2011).

Kualitas pelayanan yang baik akan meningkatkan kepuasan konsumen terhadap toko. Oleh karena itu, ketika konsumen memiliki citra yang baik terhadap toko yang dirasakan dari kualitas pelayanan toko tersebut, maka konsumen secara bersamaan merasakan citra positif toko tersebut (Carrillat et al., 2009). Kualitas pelayanan merupakan salah satu variabel penting yang mempengaruhi keputusan konsumen. Hal ini mengindikasikan bahwa ketika toko 
menyediakan kualitas pelayanan yang baik, maka kepuasan konsumen pada toko akan meningkat dan minat membeli dari produk di dalam toko tersebut juga akan meningkat (Wu et al., 2011).

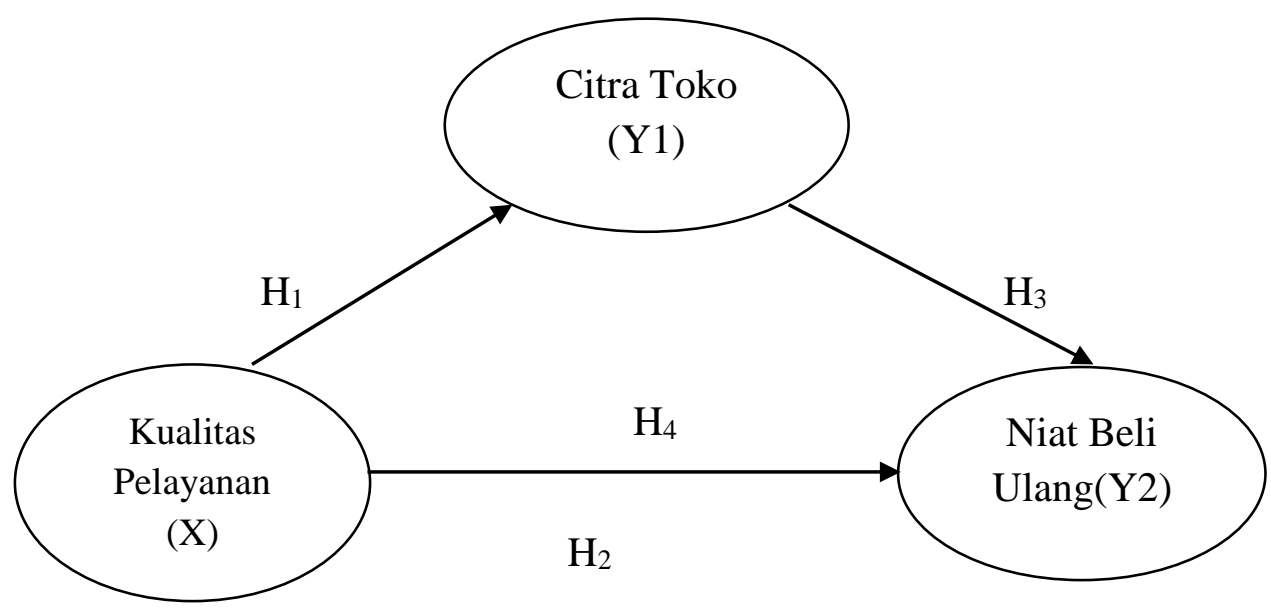

Gambar 1. Kerangka Konseptual

Penelitian ini didukung oleh penelitian yang dilakukan Fitriana dan Suzanawaty (2013) yang menyatakan bahwa terdapat pengaruh positif dan signifikan antara kualitas pelayanan dengan citra toko. Selain itu penelitian yang dilakukan oleh Wu et al. (2011) juga menyatakan bahwa kualitas pelayanan memiliki pengaruh yang positif terhadap citra toko. Kualitas layanan memiliki pengaruh terkuat pada gethok tular positif, dan citra perusahaan memiliki pengaruh terkuat pada niat beli ulang (Oktavianti dan Ellyawati., 2015). Kualitas pelayanan berpengaruh terhadap citra perusahaan Olimart PT Wina Wira Usaha (Arindita dan Sulistyaningtyas , 2013). Kualitas pelayanan memiliki pengaruh yang signifikan terhadap citra perusahaan pada PT. PLN (Persero) Rayon Malang 
Kota (Purwanti dkk, 2015). Berdasarkan dari hasil penelitian sebelumnya, maka pada penelitian ini dapat ditarik hipotesis :

$\mathrm{H}_{1}$ : Kualitas pelayanan memiliki pengaruh positif dan signifikan terhadap citra toko.

Pelayanan merupakan suatu kinerja penampilan tidak berwujud dan cepat hilang, lebih dapat dirasakan daripada dimiliki serta pelanggan lebih dapat berpartisipasi aktif dalam proses mengkonsumsi jasa tersebut. Fasilitas pelayanan pasar yang baik, kemudahan pengambilan barang, penyerahan, dan pelayanan barang secara menyeluruh merupakan pertimbangan-pertimbangan yang mempengaruhi niat beli ulang konsumen. Sikap pramuniaga yang sopan dan ramah merupakan bentuk pelayanan yang diharapkan oleh konsumen (Raharjani, 2005).

Penelitian ini didukung oleh penelitian yang dilakukan Triastuti (2012) yang menyatakan bahwa semakin baik kualitas pelayanan yang diberikan, maka semakin tinggi minat beli ulang konsumen. Senada dengan itu hasil penelitian dari Wibowo, dkk. (2013) juga menyatakan bahwa kualitas pelayanan memiliki pengaruh yang positif dan signifikan terhadap niat pembelian ulang pada Toko Buku Gramedia Yogyakarta. Selain itu, penelitian yang dilakukan oleh Bhuwana dan Sudiksa (2013) juga menyatakan bahwa kualitas pelayanan memiliki pengaruh positif dan signifikan terhadap niat pemakaian ulang jasa perbengkelan dan semakin baik kualitas pelayanan maka semakin tinggi pula minat beli ulang apotek di PT. Ratna Intan Kusuma (Kusuma, 2009). Kualitas Pelayanan di Legend 
Coffe berpengaruh positif terhadap minat beli ulang (Marieta, 2017). Berdasarkan dari hasil penelitian sebelumnya, maka pada penelitian ini dapat ditarik hipotesis: $\mathrm{H}_{2}$ : Kualitas pelayanan memiliki pengaruh positif dan signifikan terhadap niat beli ulang.

Citra toko yang menyenangkan, menarik, nyaman dan mampu menciptakan suatu atmosfir yang secara positif dapat menimbulkan niat mereka untuk memasuki toko kemudian melihat-lihat ke dalam dan akhirnya melakukan pembelian (Karmela dan Junaedi, 2009). Citra toko yang baik akan dapat mendorong konsumen untuk pasti membeli barang di toko tersebut (Nugraha, 2013). Bisa dipahami bahwa terdapat hubungan antara citra toko dan niat beli ulang, karena citra toko dapat mempengaruhi niat beli ulang konsumen (Meldarianda dan Lisan, 2010).

Penelitian ini didukung oleh penelitian yang dilakukan Ain dan Ratnasari (2015) yang menyatakan bahwa citra perusahaan berpengaruh positif terhadap niat beli ulang konsumen terhadap busana muslim Zoya. Senada dengan penelitian yang dilakukan oleh Kusuma (2009) yang menyatakan bahwa semakin baik citra perusahaan maka minat beli ulang apotek di PT. Ratna Intan Kusuma akan semakin tinggi. Selain itu, penelitian yang dilakukan oleh Yulianti (2014) juga memperlihatkan bahwa citra toko berpengaruh positif bagi niat beli ulang pada Circle K di kota Denpasar. Citra toko memiliki efek positif pada niat beli ulang produk merek toko indomaret di Yogyakarta (Nugroho dan Junaedi, 2014). Citra toko berpengaruh signifikan terhadap minat beli ulang konsumen di Charles and 
Keith Tunjungan Plaza (Widodo dkk, 2014). Berdasarkan dari hasil penelitian sebelumnya, maka pada penelitian ini dapat ditarik hipotesis:

$\mathrm{H}_{3}$ : Citra toko memiliki pengaruh positif dan signifikan terhadap niat beli ulang

Kualitas Pelayanan yang baik bertujuan untuk menimbulkan kepuasan pada diri konsumen. Apabila konsumen merasa puas, maka konsumen tersebut akan melakukan pembelian yang berulang-ulang. Memberikan citra toko yang baik juga membantu toko untuk mendapatkan konsumennya karena apabila citra yang diberikan sudah baik tentu akan terbenak dalam diri konsumen untuk mengunjungi kembali toko tersebut. Citra toko berperan sebagai pemediasi untuk meningkatkan hubungan antara kualitas pelayanan dan niat beli ulang.

Penelitian ini didukung oleh penelitian yang dilakukan Oktavianti dan Ellyawati (2015) yang menyatakan bahwa ternyata citra toko dapat sebagai variabel mediasi dengan bentuk partial mediation dan full mediation. Mediasi sebagian juga ditemukan pada kepuasan konsumen sebagai variabel mediasi antara hubungan kualitas pelayanan pada niat beli ulang. Penelitian yang dilakukan oleh Putra (2015) menyatakan bahwa harga diskon berpengaruh positif signifikan terhadap niat beli yang dimediasi oleh citra toko. Penelitian yang dilakukan oleh Adixio dan Saleh (2013) menyatakan terdapat pengaruh positif signifikan kualitas layanan terhadap niat pembelian ulang melalui mediasi kepuasan pelanggan pada restoran Solaria di Surabaya. Berdasarkan dari hasil penelitian sebelumnya, maka pada penelitian ini dapat ditarik hipotesis:

$\mathrm{H}_{4}$ : Citra Toko berpengaruh positif signifikan dalam memediasi kualitas pelayanan dengan niat beli ulang. 


\section{METODE PENELITIAN}

Penelitian ini menggunakan pendekatan kuantitatif yang berbentuk asosiatif, karena bertujuan untuk menguji variabel bebas kualitas pelayanan (X1) dengan satu variabel terikat yaitu niat beli ulang (Y2) dengan variabel mediasi yaitu citra toko (Y1).Penelitian ini membahas tentang pengaruh kualitas pelayanan terhadap citra toko, kualitas pelayanan terhadap niat beli ulang, citra toko terhadap niat beli ulang, serta meneliti tentang variabel mediasi yaitu citra toko terhadap kualitas pelayanan dan niat beli ulang.

Penelitian ini dilakukan pada Hypermart Mall Bali Galeria, Simpang Dewa Ruci Jalan By Pass Ngurah Rai Bali. Dipilihnya Hypermart Mall Bali Galeria sebagai lokasi penelitian adalah karena pertimbangan intensitas pengunjung Hypermart Mall Bali Galeria tinggi karena berada di dalam mall. Hypermart dirasa memiliki citra dan kualitas pelayanan yang baik sehingga sesuai dengan variabel-variabel yang akan diteliti. Objek dari penelitian ini adalah kualitas pelayanan dan citra toko yang dikaitkan dengan niat beli ulang di toko ritel Hypermart Mall Bali Galeria.

Niat beli ulang merupakan tanda kepuasan dari seorang konsumen terhadap produk yang pernah ia beli sehingga timbul niat untuk membeli kembali produk tersebut. Adapun indikator dalam proses niat beli ulang menurut Hawkins (1998) dalam Puspitasari (2006) yaitu : frekuensi pembelian yaitu persepsi responden tentang keinginan konsumen datang lebih dari satu kali untuk melakukan pembelian ulang; komitmen pelanggan yaitu persepsi responden tentang keterikatan konsumen untuk melakukan pembelian terhadap suatu produk; 
rekomendasi positif yaitu persepsi responden tentang saran yang baik dari konsumen yang satu ke konsumen yang lain untuk melakukan suatu pembelian di satu tempat yang sudah disarankan.

Citra toko adalah kesan yang diberikan oleh HypermartMall Bali Galeria yang kemudian ditangkap oleh konsumen baik pada saat konsumen melihat tampilan Hypermart Mall Bali Galeria, kesan pada saat konsumen berbelanja, ataupun kesan yang konsumen dengar dari konsumen lainnya terhadap baik atau buruk citra dari Hypermart Mall Bali Galeria tersebut.

Menurut Harrison dalam Suwandi (2010), informasi yang lengkap mengenai citra perusahaan meliputi empat elemen yaitu: personality adalah persepsi responden tentang keseluruhan karakteristik perusahaan seperti perusahaan yang dapat dipercaya; reputation adalah persepsi responden tentang hal yang telah dilakukan perusahaan yang dapat diyakini masyarakat seperti fasilitas yang telah diberikan oleh perusahaan; value adalah persepsi responden tentang nilai-nilai lebih yang dimiliki suatu perusahaan seperti sikap manajemen yang peduli terhadap pelanggan; corporate Identity adalah persepsi responden tentang logo, warna dan slogan dari perusahaan.

Kualitas pelayanan merupakan tindakan yang dilakukan Hypermart Mall Bali Galeria untuk memenuhi kebutuhan dan keinginan seorang pelanggan agar sesuai dengan apa yang diharapkan pelanggan. Kualitas pelayanan biasanya berhubungan dengan persepsi dan kepuasaan konsumen, apabila konsumen puas berarti Hypermart Mall Bali Galeria telah memberikan pelayanan yang baik, begitu sebaliknya. 
Tabel 2.

Operasional Variabel Penelitian

\begin{tabular}{lclcc}
\hline Variabel & NO & \multicolumn{1}{c}{ Variabel } & \multicolumn{1}{c}{ Indikator } & Sumber \\
\hline Endogen & 1 & $\begin{array}{l}\text { Niat Beli Ulang } \\
(\text { Y2) }\end{array}$ & 1. Frekuensi pembelian (Y2.1) & $\begin{array}{c}\text { Hawkins (1998) } \\
\text { dalam } \\
\text { Puspitasari } \\
\text { 2006) }\end{array}$ \\
& & 2. Komitmen pelanggan (Y2.2) & 3. Rekomendasi positif (Y2.3) &
\end{tabular}

\begin{tabular}{lll}
\hline Mediasi 2 Citra Toko (Y1) & 1. Personality (Y1.1) & Harrison dalam \\
& 2. Reputation (Y1.2) & \\
& 3. Value (Y1.3) & \\
& 4. Corporate Identity (Y1.4) & \\
& &
\end{tabular}

\begin{tabular}{|c|c|c|c|c|}
\hline \multirow[t]{2}{*}{ Eksogen } & 3 & $\begin{array}{l}\text { Kualitas } \\
\text { Pelayanan (X1) }\end{array}$ & $\begin{array}{l}\text { 1. Penampilan fasilitas fisik } \\
\text { perusahaan (tangibility) (X1.1) } \\
\text { 2. Kehandalan melayani } \\
\text { konsumen (reliability) (X1.2) } \\
\text { 3. Perhatian individu (emphaty) } \\
\text { (X1.3) } \\
\text { 4. Penanganan membantu } \\
\text { konsumen (responsiveness) } \\
\text { (X1.4) }\end{array}$ & $\begin{array}{c}\text { Aryani dan } \\
\text { Rosinta (2010) }\end{array}$ \\
\hline & & & 5. Jaminan (assurance) (X1.5) & \\
\hline
\end{tabular}

Menurut Aryani dan Rosinta (2010) kualitas pelayanan memiliki 5 indikator yaitu: tangibility yaitu persepsi responden tentang tampilan fisik atau bukti langsung dari perusahaan; reliability yaitu persepsi responden tentang kemampuan untuk melaksanakan pelayanan atau keandalan; emphaty yaitu persepsi responden tentang kepedulian berupa perhatian yang diberikan kepada konsumen; responsiveness yaitu persepsi responden tentang daya tanggap yang diberikan dalam membantu konsumen; assurance yaitu persepsi responden tentang jaminan yang diberikan oleh perusahaan terhadap konsumen. 
Populasi dalam penelitian ini adalah konsumen Hypermart Mall Bali Galeria di wilayah Denpasar. Populasi dalam penelitian ini bersifat infinite (tidak terbatas). Sampel dalam penelitian ini adalah konsumen yang pernah melakukan pembelian di Hypermart Mall Bali Galeria Denpasar. Teknik penentuan sampel yang digunakan pada penelitian ini adalah non probability sampling dengan metode purposive sampling.

\section{HASIL DAN PEMBAHASAN}

Responden dalam penelitian ini berjumlah 120 orang. Seluruh responden yang digunakan pada penelitian ini sudah dipastikan berdomisili di kota Denpasar, berpendidikan terakhir minimal SMA, dan sudah pernah melakukan pembelian di Hypermart Mall Bali Galeria. Responden dibedakan dalam jenis kelamin, usia, pekerjaan, dan pendidikan. Karakteristik responden disajikan pada Tabel 3.

Tabel 3 menunjukan bahwa responden dengan jenis kelamin laki-laki dan perempuan memiliki persentase yang sama yaitu 50 persen. Kemudian responden terbanyak dengan persentase 65 persen diperoleh dengan rentang usia 17-21 tahun dikarenakan pada rentang usia ini responden dianggap lebih memilih citra atau reputasi toko yang lebih baik dan populer dikalangan mereka. Setelah itu, diikuti oleh responden yang berusia 22 tahun sampai 26 tahun dengan jumlah persentase sebesar 15 persen pada peringkat kedua. Peringkat ketiga responden dengan rentang usia 27 tahun sampai 31 tahun mendapat jumlah persentase sebesar 6,6 persen. 
Tabel 3.

Karakteristik Responden

\begin{tabular}{|c|c|c|c|c|}
\hline \multirow{2}{*}{ No } & \multirow{2}{*}{ Variabel } & \multirow{2}{*}{ Klasifikasi } & \multirow{2}{*}{$\begin{array}{l}\text { Jumlah } \\
\text { (Orang) }\end{array}$} & \multirow{2}{*}{$\begin{array}{c}\text { Persentase } \\
(\%)\end{array}$} \\
\hline & & & & \\
\hline \multirow[t]{3}{*}{1} & Jenis Kelamin & Laki-laki & 60 & 50 \\
\hline & & Perempuan & 60 & 50 \\
\hline & & Jumlah & 120 & 100 \\
\hline \multirow[t]{7}{*}{2} & Usia (Tahun) & $17-21$ & 78 & 65 \\
\hline & & $22-26$ & 18 & 15 \\
\hline & & $27-31$ & 8 & 6,6 \\
\hline & & $32-36$ & 5 & 4,2 \\
\hline & & $37-42$ & 6 & 5 \\
\hline & & Diatas 42 & 5 & 4,2 \\
\hline & & Jumlah & 120 & 100 \\
\hline \multirow[t]{6}{*}{3} & Pekerjaan & Pelajar/Mahasiswa & 82 & 68,3 \\
\hline & & Karyawan Swasta & 26 & 21,7 \\
\hline & & PNS & 7 & 5,8 \\
\hline & & Pengusaha & 3 & 2,5 \\
\hline & & Lain-lain & 2 & 1,7 \\
\hline & & Jumlah & 120 & 100 \\
\hline \multirow[t]{6}{*}{4} & Pendidikan & SMA/Sederajat & 58 & 48,3 \\
\hline & & Diploma & 11 & 9,2 \\
\hline & & $\mathrm{S} 1$ & 45 & 37,5 \\
\hline & & $\mathrm{S} 2$ & 6 & 5 \\
\hline & & S3 & 0 & 0 \\
\hline & & Jumlah & 120 & 100 \\
\hline
\end{tabular}

Sumber : Data primer diolah, 2017

Peringkat keempat yaitu responden usia 37 tahun sampai 42 tahun dengan persentase 5 persen dan responden dengan peringkat kelima dan keenam yaitu responden usia 32 tahun sampai 36 tahun dan usia di atas 42 tahun masing-masing dengan persentase sebesar 4,2 persen.

Selain itu, pekerjaan dari responden juga memperlihatkan bahwa responden didominasi oleh pelajar ataupun mahasiswa sebesar 68,3 persen dan selanjutnya diikuti oleh responden yang berprofesi sebagai karyawan swasta sebesar 21,7 persen. Profesi PNS menempati urutan ketiga dan pada urutan ke empat yaitu 
responden yang memiliki profesi pengusaha sebesar 2,5 persen dan profesi lainlain menempati urutan terakhir dengan jumlah persentase terendah sebesar 1,7 persen. Hal ini mengindikasikan bahwa pelajar ataupun mahasiswa lebih memilih berbelanja di tempat populer yang memiliki citra toko yang baik.

Suatu instrumen dikatakan valid jika korelasi antara skor faktor dengan skor total bernilai positif dan nilainya lebih dari $0,30(\mathrm{r}>0,3)$. Tabel 4.2 menyajikan hasil uji validitas instrumen penelitian.

Tabel 4.

Uji Validitas

\begin{tabular}{llll}
\hline Variabel & Instrumen & Pearson Correlation & Keterangan \\
\hline Niat Beli Ulang (Y2) & Y2.1 & 0,524 & Valid \\
\cline { 2 - 4 } & Y2.2 & 0,589 & Valid \\
\cline { 2 - 4 } & Y2.3 & 0,620 & Valid \\
\hline Citra Toko (Y1) & Y1.1 & 0,856 & Valid \\
\cline { 2 - 4 } & Y1.2 & 0,774 & Valid \\
\cline { 2 - 4 } & Y1.3 & 0,833 & Valid \\
\cline { 2 - 4 } & Y1.4 & 0,810 & Valid \\
\hline Kualitas Pelayanan & $\mathrm{X} 1.1$ & 0,772 & Valid \\
\cline { 2 - 4 } (X1) & $\mathrm{X} 1.2$ & 0,842 & Valid \\
\cline { 2 - 4 } & $\mathrm{X} 1.3$ & 0,874 & Valid \\
\cline { 2 - 4 } & $\mathrm{X} 1.4$ & 0,899 & Valid \\
\cline { 2 - 4 } & $\mathrm{X} 1.5$ & 0,882 & \\
\end{tabular}

Sumber : Data primer diolah, 2017

Hasil uji validitas pada Tabel 4 menunjukkan bahwa seluruh variabel memiliki nilai koefisien korelasi dengan skor total seluruh item pernyataan lebih besar dari 0,30 . Hal ini menunjukkan bahwa butir-butir pernyataan sisanya dalam instrumen penelitian tersebut valid.

Suatu instrumen dikatakan reliabel, jika instrumen tersebut memiliki nilai Alpha Cronbach lebih dari 0,70. Adapun hasil dari uji reliabilitas dapat ditunjukkan pada Tabel 5 berikut : 
Tabel 5.

Uji Reliabilitas

\begin{tabular}{lll}
\hline Variabel & Cronbach's Alpha & Keterangan \\
\hline Niat Beli Ulang (Y2) & 0,834 & Reliabel \\
\hline Citra Toko (Y1) & 0,834 & Reliabel \\
\hline Kualitas Pelayanan (X1) & 0,908 & Reliabel \\
\hline Sumber : Data primer diolah, 2017 &
\end{tabular}

Hasil uji reliabilitas yang disajikan dalam Tabel 5 menunjukkan bahwa ketiga instrumen penelitian yaitu memiliki koefisien Cronbach's Alpha lebih dari 0,70. Hal ini dapat dikatakan bahwa semua instrumen reliabel sehingga dapat digunakan untuk melakukan penelitian.

Teknik pengumpulan data melalui kuisioner yang digunakan terdiri atas pernyataan yang dibuat berdasarkan masing-masing variabel, yaitu variabel niat beli ulang, citra toko, dan kualitas pelayanan. Deskripsi dari masing-masing variabel adalah sebagai berikut. Untuk mendeskripsikan penilaian responden mengenai variabel-variabel dalam penelitian perlu dilakukan konversi, di mana jawaban responden digolongkan ke dalam beberapa skala pengukuran dengan kriteria tertentu. Adapun ketentuan dalam menentukan interval kelas sebagai berikut.

$$
\text { Interval }=\frac{\text { Nilai Tertinggi }- \text { NilaiTerendah }}{\text { Jumlah Kelas }}
$$

Dikarenakan skor untuk masing-masing alternatif jawaban untuk variabel penelitian adalah minimal 1 dan maksimal 5, maka interval dihitung dengan menggunakan rumus diatas sebagai berikut.

$$
\text { Interval }=\frac{5-1}{5}=0,8
$$


I Kadek Dicki Darma Putra, Peran Citra Toko, ...

Tabel 6.

Kriteria Penilaian Variabel

\begin{tabular}{cccc}
\hline \multirow{2}{*}{ Rata-Rata Skor } & \multicolumn{3}{c}{ Kriteria Penilaian } \\
\cline { 2 - 4 } & Niat Beli Ulang & Citra Toko & Kualitas Pelayanan \\
\hline $1,00-1,79$ & Sangat Rendah & Sangat Buruk & Sangat Buruk \\
\hline $1,80-2,59$ & Rendah & Buruk & Buruk \\
\hline $2,60-3,39$ & Cukup & Cukup & Cukup \\
\hline $3,40-4,19$ & Tinggi & Baik & Baik \\
\hline 4,20 - 5,00 & Sangat Tinggi & Sangat Baik & Sangat Baik \\
\hline Sumber $:$ Data primer diolah, 2017 & &
\end{tabular}

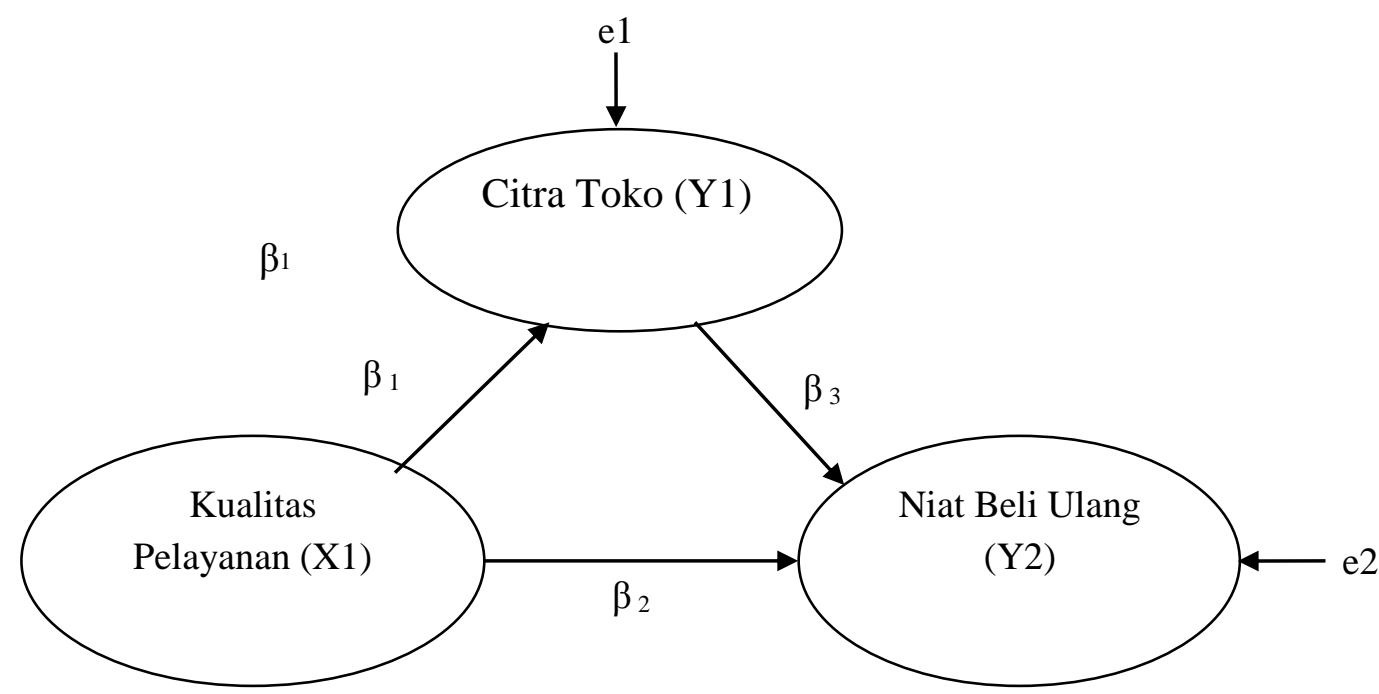

Gambar 2. Bagan Analisis Jalur

Perhitungan koefisien path dilakukan dengan analisis regresi melalui software SPSS 18.0 for Windows, diperoleh hasil yang ditunjukan pada Tabel 6.

Berdasarkan hasil analisis jalur substruktur 1 seperti yang disajikan pada

Tabel 5, maka persamaan strukturalnya adalah sebagai berikut :

$\mathrm{Y} 1=\mathrm{X}+\varepsilon_{1}$

$\mathrm{Y} 1=0,828 \mathrm{X}+\varepsilon_{1}$ 
Tabel 7.

Hasil Analisis Jalur Persamaan Regresi 1

\begin{tabular}{cccccc}
\hline \multirow{2}{*}{ Model } & \multicolumn{2}{c}{$\begin{array}{c}\text { Unstandardized } \\
\text { Coefficients }\end{array}$} & $\begin{array}{c}\text { Standardized } \\
\text { Coefficients }\end{array}$ & \multirow{2}{*}{ T } & Sig. \\
\cline { 2 - 4 } & $\mathrm{B}$ & Std.Error & Beta & & \\
\hline 1 (Constant) Kualitas & 3.421 & .729 & & 4.693 & .000 \\
Pelayanan & .614 & .038 & .828 & 16.036 & .000 \\
\hline R1 Square & & & & & 0,685 \\
F Statistik & & & & & 257,169 \\
Signifikansi & & & & & 0,000 \\
\hline Sumber : Data primer diolah, 2017 & & &
\end{tabular}

Sumber : Data primer diolah, 2017

Nilai adalah sebesar 0,828 memiliki arti bahwa Kualitas Pelayanan berpengaruh positif terhadap Citra Toko, dengan kata lain jika faktor Kualitas Pelayanan meningkat maka akan mengakibatkan peningkatan pada Citra Toko Hypermart Mall Bali Galeria sebesar 0,828.

Tabel 8.

Hasil Analisis Jalur Persamaan Regresi 2

\begin{tabular}{|c|c|c|c|c|c|}
\hline \multirow[t]{2}{*}{ Model } & \multicolumn{2}{|c|}{$\begin{array}{l}\text { Unstandardized } \\
\text { Coefficients }\end{array}$} & \multirow{2}{*}{$\begin{array}{c}\text { Standardized } \\
\text { Coefficients }\end{array}$} & \multirow[t]{2}{*}{$\mathrm{T}$} & \multirow[t]{2}{*}{ Sig. } \\
\hline & $\mathrm{B}$ & Std.Error & & & \\
\hline 1 (Constant) Kualitas & .738 & .823 & & .897 & .371 \\
\hline Pelayanan & .150 & .071 & .237 & 2.116 & .036 \\
\hline Citra Toko & .448 & .095 & .526 & 4.698 & .000 \\
\hline R1 Square & & & & & 0,539 \\
\hline F Statistik & & & & & 68,385 \\
\hline Signifikansi & & & & & 0,000 \\
\hline
\end{tabular}

Sumber : Data primer diolah, 2017

Berdasarkan hasil analisis jalur substruktur 2 seperti yang disajikan pada

Tabel 6, maka persamaan strukturalnya adalah sebagai berikut :

$$
\begin{gathered}
\mathrm{Y} 2=\mathrm{X}+\mathrm{Y} 1+\varepsilon_{2} \\
\mathrm{Y} 2=0,237 \mathrm{X}+0,526 \mathrm{Y} 1+\varepsilon_{2}
\end{gathered}
$$

Berdasarkan persamaan tersebut maka dapat disimpulkan bahwa, Nilai $\beta_{2}$ adalah sebesar 0,237 memiliki arti bahwa Kualitas Pelayanan berpengaruh positif terhadap Niat Beli Ulang, dengan kata lain jika faktor Kualitas Pelayanan 
meningkat maka akan mengakibatkan peningkatan pada Niat Beli Ulang Hypermart Mall Bali Galeria sebesar 0,237.

Nilai $\beta_{3}$ adalah sebesar 0,526 memiliki arti bahwa Citra Toko berpengaruh positif terhadap Niat Beli Ulang, dengan kata lain jika faktor Citra Toko meningkat maka akan mengakibatkan peningkatan pada Niat Beli Ulang Hypermart Mall Bali Galeria sebesar 0,526

Berdasarkan model substruktur 1 dan substruktur 2, maka dapat disusun model diagram jalur akhir. Sebelum menyusun model diagram jalur akhir, terlebih dahulu dihitung nilai standar eror sebagai berikut:

$$
\begin{aligned}
& \mathrm{Pe}_{\mathrm{i}}=\sqrt{1-\mathrm{R}_{\mathrm{i}}{ }^{2}} \\
& \mathrm{Pe}_{1}=\sqrt{1-R_{1}{ }^{2}}=\sqrt{1-0,685}=0,561 \\
& \mathrm{Pe}_{2}=\sqrt{1-R_{2}{ }^{2}}=\sqrt{1-0,539}=0,679
\end{aligned}
$$

Berdasarkan perhitungan pengaruh error (Pei), didapatkan hasil pengaruh error $\left(\mathrm{Pe}_{1}\right)$ sebesar 0,561 dan pengaruh error $\left(\mathrm{Pe}_{2}\right)$ sebesar 0,679. Hasil koefisien determinasi total adalah sebagai berikut:

$$
\begin{aligned}
\mathrm{R}^{2} \mathrm{~m} & =1-\left(\mathrm{Pe}_{1}\right)^{2}\left(\mathrm{Pe}_{2}\right)^{2} \\
& =1-(0,561)^{2}(0,679)^{2} \\
& =1-(0,315)(0,461) \\
& =1-0,145=0,855
\end{aligned}
$$

Nilai determinasi total sebesar 0,855 mempunyai arti bahwa sebesar $85,5 \%$ variasi Niat Beli Ulangdipengaruhi oleh variasi Kualitas Pelayanan dan Citra Toko, sedangkan sisanya sebesar $14,5 \%$ djelaskan oleh faktor lain yang tidak dimasukkan ke dalam model. Perhitungan pengaruh antar variabel dirangkum dalam Tabel 7 sebagai berikut. 
Tabel 9.

Pengaruh Langsung dan Pengaruh Tidak Langsung serta Pengaruh Total Kualitas Pelayanan (X), Citra Toko (Y1), dan Niat Beli Ulang(Y2)

\begin{tabular}{cccc}
\hline $\begin{array}{c}\text { Pengaruh } \\
\text { Variabel }\end{array}$ & $\begin{array}{c}\text { Pengaruh } \\
\text { Langsung }\end{array}$ & $\begin{array}{c}\text { Pengaruh Tidak Langsung Melalui Citra } \\
\text { Toko } \\
(\text { Y1 })(\boldsymbol{\beta 1} \mathbf{x} \boldsymbol{\beta 3})\end{array}$ & Pengaruh Total \\
\hline $\mathrm{X} 1 \rightarrow \mathrm{Y} 1$ & 0,828 & - & 0,828 \\
\hline $\mathrm{X} 1 \rightarrow \mathrm{Y} 2$ & 0,237 & 0,435 & 0,672 \\
\hline $\mathrm{Y} 1 \rightarrow \mathrm{Y} 2$ & 0,526 & - & 0,526 \\
\hline \multicolumn{2}{l}{ Sumber $:$ Data primer diolah, 2017}
\end{tabular}

Uji sobel merupakan alat analisis untuk menguji signifikansi dari hubungan tidak langsung antara variabel independen dengan variabel dependen yang dimediasi oleh variabel mediator. Uji Sobel dirumuskan dengan persamaan berikut dan dapat dihitung dengan menggunakan aplikasi Microsoft Excel 2007.

$$
\begin{aligned}
& Z=\frac{a b}{\sqrt{b^{2} s_{a}^{2}+a^{2} s_{b}^{2}+s_{a}^{2} s_{b}^{2}}} \\
& \operatorname{Sig}=(1-\operatorname{NORMDIST}(Z))+2)) \\
& \text { Keterangan: } \\
& \text { a }=0,828 \\
& \mathrm{~s}_{\mathrm{a}}=0,038 \\
& \mathrm{~b}=0,526 \\
& \mathrm{Sb}=0,095 \\
& Z=\frac{0,828.0,526}{\sqrt{0,526^{2} 0,038^{2}+0,828^{2} 0,095^{2}+0,038^{2} 0,095^{2}}} \\
& z=\frac{0,4355}{\sqrt{0,0004+0,0062+0,0000}} \\
& Z=\frac{0,4355}{0,08124} \\
& \mathbf{Z}=\mathbf{5 , 3 6 1}
\end{aligned}
$$

Hasil dari pengujian variabel mediasi sesuai dengan Tabel 8 yaitu citra toko didapatkan $\mathrm{Z}$ hitung sebesar 5,361>1,96 dengan tingkat signifikan sebesar 0,000<0.05 yang berarti Ho ditolak dan Hiditerimayang berarti variabel Citra Toko dinilai secara signifikan memediasi variabel Kualitas Pelayananpada niat beli ulang konsumen Hypermart Mall Bali Galeria di Denpasar. 
Tabel 10.

Hasil Uji Sobel

\begin{tabular}{cc}
\hline Nilai Z & Sig \\
\hline 5,361 & 0,000
\end{tabular}

Sumber : Data primer diolah, 2017

\section{Pengaruh Kualitas Pelayanan Terhadap Citra Toko}

Pengujian hipotesis pada pengaruh Kualitas Pelayanan terhadap Citra Toko menunjukkan bahwa Kualitas Pelayanan secara signifikan berpengaruh positif terhadap Citra Toko. Ini berarti semakin baiknya Kualitas Pelayanan yang diberikan oleh Hypermart Mall Bali Galeria maka akan meningkatkan Citra Toko dari Hypermart Mall Bali Galeria.

Hasil penelitian ini mendukung penelitian dari Fitriana dan Suzanawaty (2013), Wu et al. (2011), Oktavianti dan Ellyawati (2015), Arindita dan Sulistyaningtyas(2013), Purwanti, dkk(2015) yang menjelaskan bahwa Kualitas Pelayanan berpengaruh positif dan signifikan terhadap Citra Toko.

Pengujian hipotesis pada pengaruh Kualitas Pelayanan terhadap Niat Beli Ulang menunjukkan bahwa Kualitas Pelayanan secara signifikan berpengaruh positif terhadap Niat Beli Ulang. Ini berarti semakin baiknya Kualitas Pelayanan yang diberikan oleh Hypermart Mall Bali Galeria maka akan meningkatkan Niat Beli Ulang konsumen di Hypermart Mall Bali Galeria.

Hasil penelitian ini mendukung temuan dari Triastuti (2012), Wibowo, dkk. (2013), Bhuwana dan Sudiksa (2013), Purnama (2009), dan Marieta(2017) yang 
menjelaskan bahwa Kualitas Pelayanan berpengaruh positif dan signifikan terhadap Niat Beli Ulang.

\section{Pengaruh Citra Toko Terhadap Niat Beli Ulang}

Pengujian hipotesis pada pengaruh Citra Toko terhadap Niat Beli Ulang menunjukkan bahwa Citra Toko secara signifikan berpengaruh positif terhadap Niat Beli Ulang. Ini berarti semakin baiknya Citra Toko yang diberikan oleh Hypermart Mall Bali Galeria maka akan meningkatkan Niat Beli Ulang konsumen di Hypermart Mall Bali Galeria.

Hasil penelitian ini mendukung temuan dari Ain dan Ratnasari (2015) , Kusuma (2009), Yulianti (2014), Nugroho dan Junaedi (2014), Widodo, dkk (2014) yang menjelaskan bahwa Citra Toko berpengaruh positif dan signifikan terhadap Niat Beli Ulang.

Peran Citra Toko dalam Memediasi Kualitas Pelayanan pada Niat Beli Ulang

Pengujian hipotesis pada peran Citra Toko dalam memediasi Kualitas Pelayanan terhadap Niat Beli Ulang menunjukkan bahwa Citra Toko mampu memediasi pengaruh Kualitas Pelayanan terhadap Niat Beli Ulang. Ini berarti Citra Toko memediasi pengaruh Kualitas Pelayanan terhadap Niat Beli Ulang secara parsial. Dengan kata lain, Citra Toko memperkuat pengaruh Kualitas Pelayanan ke Niat Beli Ulang yang semula bernilai 0,237 namun setelah adanya Citra Toko sebagai variabel mediasi pengaruh Kualitas Pelayanan ke Niat Beli Ulang meningkat menjadi 0,672. 
Hasil penelitian ini mendukung temuan dari Oktavianti dan Ellyawati (2015), Putra (2015), Adixio dan Saleh (2013)yang menjelaskan bahwa hubungan antara Kualitas Pelayanan yang diterapkan bersamaan dengan Citra Toko terhadap Niat Beli Ulang akan menunjukkan hasil yang positif dan signifikan.

Implikasi teoritis penelitian ini berhubungan dengan kontribusinya bagi perkembangan konsep dalam bidang ilmu pemasaran. Hasil temuan penelitian ini memperkuat penelitian-penelitian sebelumnya yang menunjukkan bahwa citra toko dan kualitas pelayanan dapat mempengaruhi niat beli ulang konsumen.

Kualitas pelayanan berpengaruh terhadap citra toko dan niat beli ulang konsumen. Ini membuktikan bahwa apabila kualitas pelayanan yang diberikan oleh suatu toko semakin baik, maka akan mengakibatkan citra toko juga akan semakin baik dibenak konsumen. Kualitas pelayanan yang baik juga akan mempengaruhi niat konsumen untuk datang dan membeli kembali di toko tersebut. Citra toko juga sebagai pemediasi untuk menguatkan pengaruh antara kualitas pelayanan dengan niat beli ulang. Artinya apabila kualitas pelayanan dan citra toko yang diberikan sudah baik, maka akan mempengaruhi niat beli ulang konsumen tersebut.

\section{SIMPULAN DAN SARAN}

Berdasarkan hasil pembahasan, dapat ditarik beberapa simpulan, sebagai berikut: Kualitas Pelayanan secara signifikan berpengaruh positif terhadap Citra Toko. Ini berarti semakin baiknya Kualitas Pelayanan yang diberikan oleh Hypermart Mall Bali Galeria maka akan meningkatkan Citra Toko dari Hypermart Mall Bali Galeria. Kualitas Pelayanan secara signifikan berpengaruh positif 
terhadap Niat Beli Ulang. Ini berarti semakin baiknya Kualitas Pelayanan yang diberikan oleh Hypermart Mall Bali Galeria maka akan meningkatkan Niat Beli Ulang konsumen di Hypermart Mall Bali Galeria.

Citra Toko secara signifikan berpengaruh positif terhadap Niat Beli Ulang. Ini berarti semakin baiknya Citra Toko yang diberikan oleh Hypermart Mall Bali Galeria maka akan meningkatkan Niat Beli Ulang konsumen di Hypermart Mall Bali Galeria. Citra Toko mampu memediasi pengaruh Kualitas Pelayanan terhadap Niat Beli Ulang. Ini berarti Citra Toko memediasi pengaruh Kualitas Pelayanan terhadap Niat Beli Ulang secara parsial. Dengan kata lain, Citra Toko memperkuat pengaruh Kualitas Pelayanan ke Niat Beli Ulang.

Berdasarkan hasil analisis dan simpulan, Pihak Hypermart Mall Bali Galeria sebaiknya lebih meningkatkan kelengkapan produk-produknya baik dari produk "food" maupun "nonfood" terutama yang susah ditemukan di gerai ritel lainnya agar pihak konsumen merasa segala kebutuhan yang dicari semuanya terdapat di Hypermart Mall Bali Galeria sehingga dapat meningkatkan niat beli ulang di Hypermart Mall Bali Galeria. Pihak Hypermart Mall Bali Galeria sebaiknya lebih selektif dalam merekrut karyawan dan memberikan pelatihan yang baik terhadap karyawan-karyawannya agar lebih memiliki rasa peduli dan tanggap terhadap konsumennya, baik dalam melayani permintaan maupun keluhan untuk meningkatkan citra dan kualitas pelayanannya.

\section{REFERENSI}

Adixio, R.F., dan Laila Saleh. 2013. Pengaruh Kualitas Layanan dan Nilai yang Dirasakan Terhadap Niat Pembelian Ulang Melalui Mediasi Kepuasan Pelanggan Restoran Solaria di Surabaya. Journal of Business and Banking, 3(2): 151-164. 
Agustin, Grienda.2011. Pengaruh Persepsi Kualitas Pelayanan Dan Kepuasan Konsumen Pada Minat Pembelian Ulang (Studi Pada Konsumen Toserba Luwes `Paur). Skripsi. Fakutas Ekonomi Universitas Sebelas Maret Surakarta.

Agyapong, Gloria K.Q. 2011. The Effect of Service Quality on Customer Satisfaction in the Utility Industry - A Case of Vodafone (Ghana), International Journal of Business and Management. 6(5): 1-13.

Arindita, Aloysius Reza., Ike Devi Sulistyaningtyas. 2013. Pengaruh Kualitas Pelayanan Terhadap Citra Perusahaan di Olimart PT. Wina Wira Usaha. Skripsi. Program Studi Ilmu Komunikasi Fakultas Ilmu Sosial dan Politik Universitas Atma Jaya Yogyakarta.

Aryani, Dwi dan Febrina Rosinta. 2010. Pengaruh KualitasLayanan Terhadap Kepuasan Pelanggan dalam Membentuk Loyalitas Pelanggan. Bisnis dan Birokrasi. Jurnal Ilmu Administrasi dan Organisasi, 17 (2): 114-126.

Bao,Yongchuan., Yeqing Bao ., Shibin Sheng. 2011. Motivating Purchase of Private Label Brands : Effect of Store Image, Product Signatureness, and Quality Variation. Journal of Business Research, 64: 220-226.

Beristain, Jose juanand Pillar Zorrila. 2011. The Relationship Between Store Image and Store Brand Equity : A Conceptual Framework and Evidence From Hypermarkets. Journal of Retailing and Consumer Service, 18: 562-574.

Bhuwana, Made Bagus Rangga dan Ida Bagus Sudiksa. 2013. Pengaruh Kualitas Layanan dan Kepuasan Pelanggan Terhadap Niat Pemakaian Ulang Jasa Service Pada Bengkel Toyota Auto 2000 Denpasar, E-Jurnal Manajemen Universitas Udayana. 2 (4): 2302-8912.

Firdiana, Emilia, Susilo Toto Rahardjo. 2016. Pengaruh Store Atmosphere, Promosi, dan Pendapatan Terhadap Impulse Buying Konsumen Hypermart di Kota Semarang. Skripsi. Fakultas Ekonomika dan Bisnis Universitas Diponegoro.

Iswayanti, Ika Putri. 2010. Analisis Pengaruh Kualitas Produk, Kualitas Layanan, Harga, Tempat terhadap Keputusan Pembelian (Studi pada Rumah Makan "Soto Angkring Mas Boed" di Semarang). Skripsi. Fakultas Ekonomi Universitas Diponogoro.

Karmela, F. Dan Junaedi J. 2009. Pengaruh Store Atmosfir Terhadap Niat beli ulang Konsumen pada toserba Griya Kuningan. Jurnal Manajemen, 5 (9): 94106. 
Kheng, L.L., Osman Mohamad., T. Ramayah., Rahim Mosahab. 2010. The Impact of Service Quality on Customer Loyalty: A Study of Banks in Penang, Malaysia. International Journal of Marketing Studies, 2(2): 57-66.

Kotler, Philip. 2003. Marketing Management. Eleventh Edition. Upper Saddle River, New Jersey: Pearson Eduction, Inc.

Kotler,Philip. 2006. Manajemen Pemasaran, Jilid I. Edisi kesebelas. PT Indeks: Jakarta.

Kotler, Philip dan Kevin Lane Keller. 2008. Manajemen Pemasaran, Jilid 1. Jakarta: Erlangga.

Kotler, Philip, Kevin L. Keller, Swee Hoon Ang, SiewMeng Leong, and Chin Tiong Tan. 2006. Marketing Management, An Asian Perspective. Fourth Edition. Pearson Education South Asia Pte Ltd, Jurong, Singapore.

Kusuma, Adhi Rah. 2009. Pengaruh Kualitas Pelayanan, Kompetensi Tenaga Penjualan, dan Citra Perusahaan Terhadap Minat Beli Ulang (Studi pada PT. Ratna Intan Kusuma di Semarang). Tesis. Program Pasca Sarjana Magister Manajemen Universitas Diponegoro Semarang.

Kusuma, Made Andi. 2016. Pengaruh Celebrity Endorse, Brand Image, dan Kualitas Produk Terhadap Niat Beli Sepeda Moto Honda Vario 125 Di Kota Denpasar. Skripsi. Fakultas Ekonomi dan Bisnis Universitas Udayana Denpasar.

Marieta, Prilando Dewi. 2017. Pengaruh Kualitas Pelayanan Terhadap Minat Beli Ulang (Studi Kasus Pada Legend Coffee di Yogyakarta). Skripsi. Program Studi Manajemen Fakultas Ekonomi Universitas Sanata Dharma Yogyakarta.

Meng, Shiang-Min, Ci-Chenli.,2011. The Relationships of Cruise Image, Percieved Value, Satisfaction, and Post-Purchase Behavioral Intention on Taiwanese Tourist. African Jurnal of Business Management, 5(1): 404-422.

Nugraha, B.A. 2013. Persepsi Terhadap Store Atmosfir dengan Niat beli ulang Konsumen di Hypermart. Jurnal Psikologi, 1(2): 515-528.

Nugroho, Aan.,Shellyana Junaedi. 2014. Pengaruh Citra Toko, Kualitas Pelayanan, Citra Produk Merek Toko, Risiko yang dirasakan dan Kesadaran Harga pada Niat Membeli Ulang Produk Merek Toko Indomaret di Yogyakarta. Tesis. Program Studi Manajemen Universitas Gadjah Mada Yogyakarta.

Oktavianti, Maria Christina Dwi dan J.Ellyawati. 2015. Pengaruh Kualitas Layanan, Citra Perusahaan, Dan Kepuasan Pada Gethok Tular Positif serta Niat 
Beli Ulang. Program studi manajemen. Fakultas Ekonomi Universitas Atma Jaya Yogyakarta.

Purnama, Wahyu. 2016. Pengaruh Bauran Eceran (Retailing Mix) Terhadap Kepuasan Konsumen Pada Swalayan Rizki di Pasir Pengaraian Kabupaten Rokan Hulu. Skripsi. Universitas Islam Negeri Sultan Syarif Kasim Riau.

Purwanti, Neni Dyah., Sugiono., Dewi Hardiningtyas. 2015. Analisis Pengaruh Kualitas Pelayanan dan Citra Perusahaan Terhadap Kepuasan dan Loyalitas Pelanggan (Studi Kasus PT. PLN (Persero) Rayon Malang Kota). Jurnal Rekayasa dan Manajemen Sistem Industri. 3(2): 1-13.

Puspitasari, Diana. 2006. Analisis Pengaruh Persepsi Kualitas dan Kepuasan Pelanggan Terhadap Minat Beli Ulang. Tesis. Program Studi Magister Manajemen Universitas Diponegoro.

Putra, Dandy Bima Laksmana. 2015. Pengaruh Harga Diskon Terhadap Niat Pembelian Dengan Citra Toko Sebagai Variabel Pemediasi Pada Pengunjung Metro Ciputra World Di Surabaya. STIE Perbanas Surabaya.

Qin, Hong and Victor. R. Prybutok. 2009. Service Quality, Customer Satisfaction, and Behavioral Intentions in Fast Food Restaurants. International Journal of Quality and Service Sciences, 1(1): 78-95.

Raharjani, Jeni. 2005. Analisis Faktor-faktor yang Mempengaruhi Keputusan Pemilihan Pasar Swalayan Sebagai Tempat Berbelanja (Studi Kasus Pada Pasar Swalayan di Kawasan Seputar Simpang Lima Semarang). Jurnal Studi Manajemen \& Organisasi, 2(1): 1-15.

Sulistiono, Ari Budi. 2010. Pengaruh Kualitas Pelayanan, Fasilitas dan Lokasi Terhadap Keputusan Menginap (Studi Pada Tamu Hotel Srondol Indah Semarang). Skripsi. Fakultas Ekonomi Universitas Diponegoro.

Suwandi, Iman Mulyana Dwi. 2010. Citra Perusahaan. Seri Manajemen Pemasaran. www.e-iman.uni.cc.

Tariq, M.I., M.R. Nawaz., M.M Nawaz., Hasim Awaiz Butt. 2013. Customer Perception About Branding and Puchase Intention : A Study of Fincgin An Emerging Market. Journal Of Basic and Applied Scientific Research, 3 (2): 340-347.

Triastuti, Freida. 2012. Analisis Pengaruh Kualitas Pelayanan, Kualitas Produk dan Promosi Penjualan Terhadap Minat Beli Ulang(Studi Pada Konsumen Buket Koffee and Jazz). Skripsi. Fakultas Ekonomika dan Bisnis Universitas Diponegoro Semarang. 
Upadhana, Ida Bagus Ary dan Ni Made Rastini. 2014. Pengaruh Atmosfir Toko, Kualitas Pelayanan, Kelengkapan Barang dan Kewajaran Harga, Terhadap Niat Beli Konsumen Pada Toko Painluva Seminyak. E-Jurnal Manajemen Unud. 4(4): 1241-1256.

Wibowo, Sarwo Eddy., Endang Ruswanti., Unggul Januarko. 2013. Pengaruh Persepsi Kualitas Pelayanan Terhadap Niat pembelian Ulang Pada Toko Buku Gramedia Yogyakarta. Jurnal Ekonomi, 4(1): 1-12.

Widjajanti, Kesi Dan Nina Ernawati. 2012. Analisis Pengaruh Kualitas Pelayanan Terhadap Kepuasan Pelanggan Di Warnet Usm. J. Dinamika Sosbud, 14(1) :63-71

Widodo, PriscaPradita., Edwin Japarianto., Michael Adiwijaya. 2014. Pengaruh Citra Toko dan Kualitas Pelayanan Terhadap Minat Beli Ulang konsumen di Charles and Keith Tunjungan Plaza. Skripsi. Program studi MAnajemen Universitas Kristen Petra.

Wijayanti, R.F., Suharyono., Imam Suyadi. 2013. Pengaruh Citra Toko, Variasi Kualitas, Product Signatureness Terhadap Kualitas yang Dipersepsikan dan Dampaknya pada Minat Pembelian Produk Private Label Brands. Jurnal Profit e-Journal Fakultas Ilmu Administrasi Universitas Brawijaya, 7(1): 76-86.

Wu, Paul C.S., Gary Yeong-Yuh Yeh, Chieh- Ru Hsiao. 2011. The Effect of Store Image and Service Quality on Brand Image and Purchase Intention for Private Label Brands. Australasian Marketing Journal, 19(1): 30-39.

Yulianti, Ni Made Dhian Rani., Ni Wayan Sri Suprapti., Ni Nyoman Kerti Yasa. 2014. Pengaruh Citra Toko Terhadap Kepuasan Pelanggan dan Niat Beli Ulang Pada Circle K di Kota Denpasar. Jurnal Manajemen Strategi Bisnis dan Kewirausahaan, 8(1): 36-44.

www.Bali-Bisnis.com diakses tanggal 10 Januari 2014

www.hypermart.co.id diakses tanggal 31 Agustus 2017 